\title{
Long non-coding RNA: its evolutionary relics and biological implications in mammals: a review
}

\author{
Jasdeep Kaur Dhanoa, Ram Saran Sethi, Ramneek Verma, Jaspreet Singh Arora \\ and Chandra Sekhar Mukhopadhyay * (D)
}

\begin{abstract}
The central dogma of gene expression propounds that DNA is transcribed to mRNA and finally gets translated into protein. Only $2-3 \%$ of the genomic DNA is transcribed to protein-coding mRNA. Interestingly, only a further minuscule part of genomic DNA encodes for long non-coding RNAs (IncRNAs) which are characteristically more than 200 nucleotides long and can be transcribed from both protein-coding (e.g. H19 and TUG1) as well as noncoding DNA by RNA polymerase II. The IncRNAs do not have open reading frames (with some exceptions), 3'untranslated regions (3'-UTRs) and necessarily these RNAs lack any translation-termination regions, however, these can be spliced, capped and polyadenylated as mRNA molecules. The flexibility of IncRNAs confers them specific 3Dconformations that eventually enable the IncRNAs to interact with proteins, DNA or other RNA molecules via base pairing or by forming networks. The IncRNAs play a major role in gene regulation, cell differentiation, cancer cell invasion and metastasis and chromatin remodeling. Deregulation of IncRNA is also responsible for numerous diseases in mammals. Various studies have revealed their significance as biomarkers for prognosis and diagnosis of cancer. The aim of this review is to overview the salient features, evolution, biogenesis and biological importance of these molecules in the mammalian system.
\end{abstract}

Keywords: Long non-coding RNA, Biogenesis, Disease biomarker, Evolution, Mammals

\section{Background}

The organization of eukaryotic genome is very complex. Almost 98\% of the human genome does not encode proteins [109]. This non-coding DNA was assumed to be a "barren land" with no apparent functionality in protein synthesis and thus erstwhile it was termed as "junk DNA" [50, 73, 75]. However, the non-coding, intergenic DNA was later found to be a treasure of information that can be deciphered in the form of nucleotide elements (repetitive, transposable, interspersed elements etc) and different non-coding RNAs (rRNAs, tRNAs, regulatory RNAs etc). The RNA molecules lacking protein-codingcapacity are known as non-coding RNAs (ncRNAs). How much non-coding sequences are functional is still a matter of debate. The reports published by Encyclopedia of DNA elements (ENCODE) revealed

\footnotetext{
* Correspondence: csmbioinfo@gmail.com

School of Animal Biotechnology, Guru Angad Dev Veterinary and Animal Sciences University, Ludhiana, Punjab, India
}

that approximately $80.4 \%$ of the genome is involved in some sort of biochemical activity including chromatin structure, histone modification and RNA transcription etc. [71]. The non-coding transcripts less than 200 bases are called small non-coding RNA and comprise of tRNA, rRNA, miRNA, snoRNA, piwi-interacting RNA (pi-RNA) etc. [47]. The proportion of different ncRNAs to the total amount of RNA in a healthy eukaryotic cell, other than rRNA (80-90\%) and tRNA (10-15\%), ranges between 0.002 to $0.2 \%$ [15]. On the contrary, RNA molecules that are of more than 200 bases in length are known as long non-coding RNA (lncRNA) [82].

The lncRNAs and other non-coding RNAs including miRNAs (21-24 bases) and piRNAs (26-31 bases) are involved in epigenetic modification of DNA, and regulation of transcriptional and post-transcriptional gene expression [25, 69]. In the course of time, different non-coding RNAs (antisense RNAs, snoRNAs, miRNAs, piRNAsetc) have been discovered in animals and plants.

(c) The Author(s). 2018 Open Access This article is distributed under the terms of the Creative Commons Attribution 4.0 International License (http://creativecommons.org/licenses/by/4.0/), which permits unrestricted use, distribution, and 
Of late, considerable research emphasis has been given towards lncRNAs and their diverse role in various diseases in animals, especially human and mice. H19, an imprinted long non-coding RNA gene that encodes an untranslated RNA, is transcribed only from maternally inherited alleles. This feature is responsible for its role as a negative regulation of body weight and cell proliferation. The maternal disruption of this gene in mice showed somatic overgrowth of heterozygotes whereas no effect was noticed during disrupted paternal inheritance [57]. The study showed that transgenic mice lacking functional H19 exhibit normal development, however, other experiments in mice revealed that overexpression of $\mathrm{H} 19$ affects their prenatal viability $[43,49]$. The IncRNAs exercise a very wide variety of functions in animals, which have been discussed later in this review. Certain lncRNAs are reported to be associated with counteracting toxic conditions in the human body. The lncRNAs associated with toxicological responses to various xenobiotics (Benzene, Phenobarbital, Cadmium etc.), in human, has also been reported [14].

The lncRNAs exhibit their biological functions by acting as cis- or trans- regulators in biological processes $[63,79,95]$. The lncRNAs that control chromatin structure interact with nucleosome remodeling factors as well as chromatin modifying enzymes [33]. Such long noncoding RNAs usually have limited coding potential due to the absence of open reading frames, 3 - - UTR and termination region. In this review, we are going to outline the literature findings of the basic features, functions and differential role of lncRNAs in the biological system.

\section{Features of IncRNA Length}

As discussed above, the non-coding transcripts that do not encode proteins and are more than 200 nucleotides in length are known as long non-coding RNAs (lncRNAs). The length of a lncRNA can be more than 2 $\mathrm{Kb}$ while their coding potential is less than 100 amino acids [5]. Kaur and colleagues showed that in the human genome $20 \%$ of the transcriptional progress would be associated with protein-coding genes. This information illustrates that lncRNAs are four times longer than the coding RNA sequence [5].

\section{Location in genome}

The lncRNAs are harbored mostly in poorly conserved regions in the genome including the intronic regions of genes [51]. Besides, some IncRNAs are reported to be transcribed from one of the strands of a DNA sequence [61] within the protein-coding locus. The genomic locations of the lncRNAs bear direct association with their evolutionary conservedness [52, 53]. Research findings and scientific discussions suggest that plethora of lncRNAs are evolutionarily conserved [54] howbeit to lesser extent as compared to that of the protein-coding genes [55]. Interestingly, the promoter-regions of the lncRNAs are more conserved as compared to the sequence of the lncRNAs [56]. The presence of open reading frames in some lncRNAs makes these molecules difficult to distinguish from protein-coding RNAs [17]. The lncRNA gene ' $\mathrm{X}$ Inactive Specific Transcript' (or Xist), responsible for X-chromosome inactivation, is an example of IncRNA located within a less conserved region in the genome [81].

\section{Action}

Different families of lncRNAs exercise varying modes of action for gene expression regulation and protein synthesis. These non-coding RNAs (ncRNAs) can act as scaffolds in sub-nuclear domains or can possess secondary structures to interact with DNA, RNA, and protein (http://www.exiqon.com/lncRNA). Long non-coding RNAs havecell-specific expression.It has been reported that transcription of individual lncRNAs occurs at a specifictime; hence they can serve as molecularsignals to respond to diverse stimuli [103].

\section{Cis- and trans-regulating action}

The specific category of RNAs that exhibit sequence-com plementarity to other RNA transcripts is known as natural antisense transcripts (NATs). The trans-NATs and their respective targets are physically located in different loci on the genome, like miRNAs. While the cis-NATs and their targets are located on the same locus, but opposite strands of the DNA. These cis-NATs were firstly identified in viruses, then prokaryotes and finally in eukaryotes. In eukaryotes (except nematodes), approximately $5-29 \%$ of the transcriptional units are involved in the overlap [51]. The cis-NATs are transcribed by RNApolymerase II which shows its involvement in mRNA processing. The interaction of sense and antisense transcripts suggests the role of NATs in gene expression regulation. Besides that, it has also been reported that in case of RNA hybrid formation and transcription of gene locus in both orientations can also induce gene silencing or can trigger an immune response [108].

\section{Comparison with miRNA}

miRNAs and lncRNAs, both are non-coding in nature. miRNAs are $\sim 22$ nucleotides long as compared to $8-10$ times longer lncRNAs. The exact functions of lncRNAs are not clear yet but it has been reported that both miRNA and lncRNAs act as regulators for controlling biological processes at post-transcriptional repression of protein-coding genes [101, 102, 105]. Besides,lncRNAs can also act as miRNA sponges and can reduce their regulatory effect on mRNA [78]. Experimental detection 
of the human genome has identified approximately 2000 different miRNAs and around 50,000 lncRNAs [15, 21, 34].

\section{Classification of IncRNAs}

The nomenclature and symbols of 319 human-lncRNAshave been approved by the HUGO-Gene Nomenclature Committee (HGNC) (https://www.genenames.org/cgi-bin/ genefamilies/set/788). The lncRNAs are classified on the basis of structure, function, localization, metabolism, and interaction with protein-coding genes or other DNA elements [4]. Secondary and tertiary structures of IncRNA are greatly conserved as compared to its primary structure. The structure-function relationship study of these high molecular weight molecules is challenging because they are difficult to crystallize [58, 59]. Broadly, the lncRNAs can be divided into 5 categories (Fig. 1):

- sense lncRNAs

- antisense lncRNAs

- bidirectional lncRNAs

- intronic lncRNAs and

- intergenic lncRNAs

The aforementioned diversified function classifications can be clustered according to the 3 different modes of regulation. Firstly, as a competitor, it can bind to DNA binding proteins and can inhibit their attachment to the target (viz. transcription factors). For example, lncRNA can affect DNA methylation by inhibiting binding of DNMT1 to target DNA that ultimately affects transcriptional activation of the target gene [38]. Secondly, as a recruiter, lncRNA can reinforce DNA methylation by recruiting epigenetic modifiers to some target sites [113]. Lastly, lncRNA can act as a precursor of miRNA through digestion with some RNases such as Dicer [45].

\section{Biogenesis of the IncRNAs}

The lncRNA can be transcribed from intergenic, exonic or the distal protein-coding regions of the genome by the enzyme RNA-polymerase II (Fig. 1). Then the pre-mature lncRNA gets 3 '-polyadenylated and capped on the $5^{\prime}$-end with methyl-guanosine [60]. Often it undergoes alternative splicingwhich is essential to generate protein diversity [26]. The mechanism of alternative splicing can be classified in three ways. Firstly, lncRNAs interact with specific splicing factors and then form RNA-RNA duplexes with pre-mRNA molecules and finally, they affect the chromatin remodeling, thus complete the splicing of target genes [87]. For example, LINC-HELLP, a $205 \mathrm{~kb}$-lncRNA, which is suggested to be involved in pregnancy-associated disease HELLP and splicing regulation. The purification and mass spectrometry experiments revealed that splicing components (including the splicing-related factors Y-Box Binding Protein 1 (YBX1), and Poly(RC) Binding Proteins 1 and 2) and the ribosomal machinery recognizesthis lncRNA. The molecular mechanisms of splicing regulation by this IncRNAare not clear yet, but it was demonstrated that due to mutations in HELLP patients, some portion ( 5 ' -end up to the middle) of the LINC-HELLP transcript loses its ability to interact with its protein partners. On the other hand, binding increases with mutations at the far 3 '-end [87]. There are some exceptions of functional lncRNAs which are not polyadenylated viz. antisense,as-Oct4-pg5' and brain associated $B C 200^{\prime}$ [11, 35]. In general,

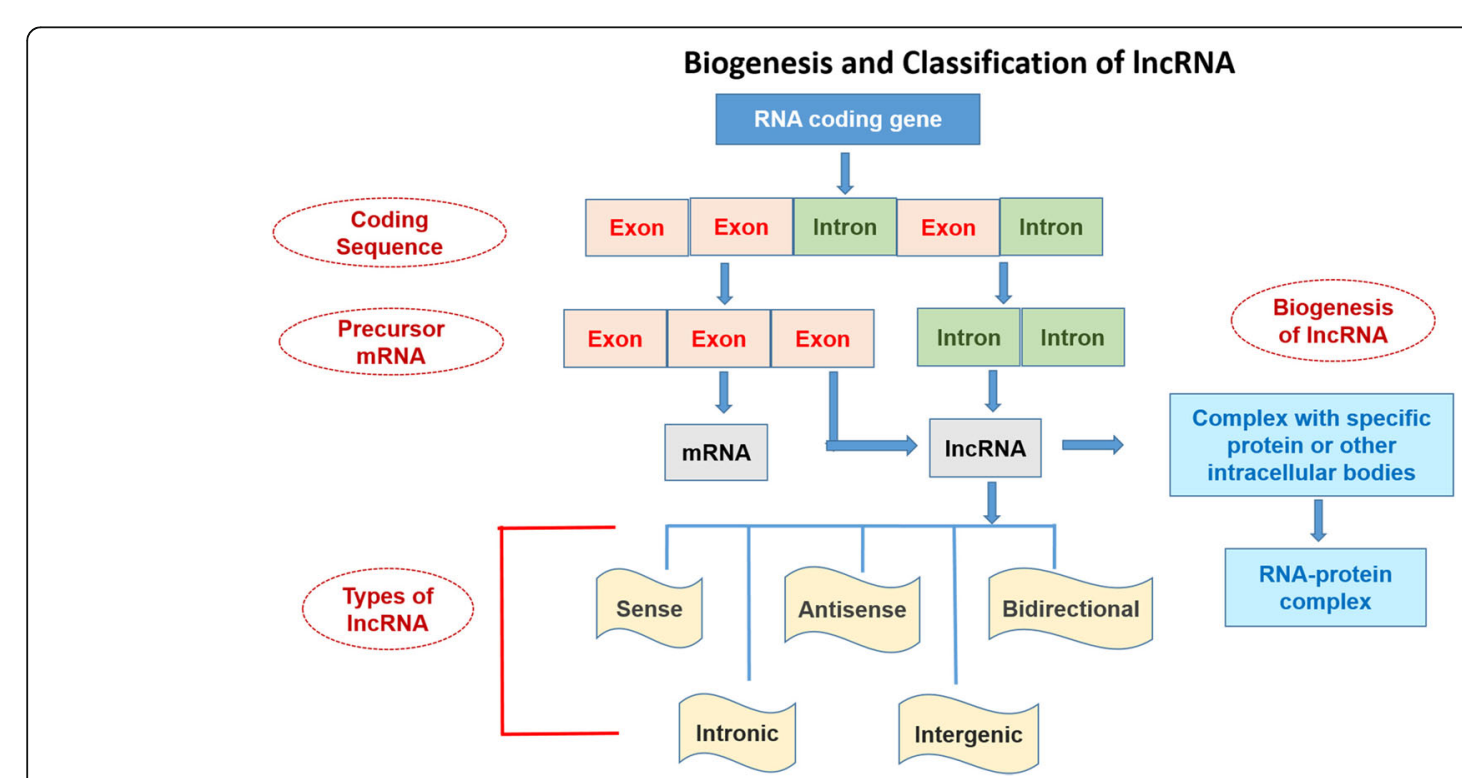

Fig. 1 Biogenesis and classification (on the basis of localization) of IncRNAs in humans and other animals 
lncRNA-encoding genes consist of own promoters and have their transcription factors (TFs) and unique DNA motifs [14].

Epigenetic modification plays role in lncRNA biogenesis. Histone-methylation plays a major role in transcriptional regulation. Histone $\mathrm{H} 3$ lysine 4 (H3K4) methylation is the symbol of transcription activation whereas H3K27 trimethylation indicates gene silencing. Various lncRNAs including HOTTIP, XIST, FIRRE etc. are involved in transcriptional gene activation and organization of $3 \mathrm{D}$ nuclear architecture [14]. On the other hand, the decoys of lncRNAs such as Alu transcripts or lncRNA-DNA triplex can inhibit the transcriptional regulation through binding to RNA polII [64]. Binding of different transcription factors (TFs) to lncRNA forms a nascent transcript which ultimately regulates mRNA processing through alternative splicing. This binding of lncRNAs to mRNA can increase or inhibit translation or can promote mRNA decay [6]. Experimental data from small RNA deep sequencing (sRNA-Seq) has suggested that IncRNA can encode small functional RNA too [41]. Mature lncRNAs can be present in the nucleus and/or cytoplasm [80]. Despite the fact that the cytoplasmic lncRNAs are not translated, but small peptides have been identified that were generated from IncRNAs through their association with ribosomes [30]. Some findings indicate that transcriptionally active pseudogenes can also produce these molecules or they can also be transcribed from the promoter or intergenic regions [25].

\section{Divergent functions of IncRNAs}

Most of the lncRNAs, although non-coding in nature, have a diverse role in disease and biological developmental processes. The exact function of lncRNA and its mode of action warrants in-depth study. However, in general, lncRNAs are found to play important role in gene expression regulation of various diseases including cancer. The lncRNA can implement its function in four different ways [3]:

\section{Signals}

The production and presence of signal factors of lncRNAs are an indicator of their transcriptional activity (e.g. KCNQ1ot1 and Xist) [19]. Some lncRNA transcripts such as CCND1 activate or deactivate the natural functions of target protein targets (that are allosterically modified) via intrinsic catalytic activities [106].

\section{Decoys}

Molecular decoys (viz. Gas5, PANDA etc) are polynucleotides that negatively regulate an effector by preventing access of regulatory proteins to DNA. Gas5 is a hairpin-structured lncRNA (resembles glucocorticoid receptors of DNA) that act as a decoy during growth factor starvation. It releases the receptors of DNA during starvation condition and prevents the transcription of metabolic genes [85].

\section{Guides}

The lncRNAs are required for proper localization of specific proteins including ribonucleoprotein complexes. Homeobox antisense intergenic RNA (HOTAIR) is an example of guide lncRNA to localize polycomb repressor complex2 (PRC2) in developmental and cancer-related gene expression. It is associated with tumor invasiveness and metastasis in gastrointestinal, liver, breast and pancreatic cancers [27].

\section{Scaffolds}

The lncRNAs can serve as adaptors to bind more than 2 protein partners, thus are involved in structural roles. The telomerase RNA TERC (TERRA), an example of RNA scaffold, is responsible for telomerase function [99].

Apart from the aforementioned functions, IncRNAs have been reported to be functional in some substructures of mouse brain [66], and have some role associated with transcriptional factors involved in conferring pluripotency to cells [16]. Long intergenic non-coding RNAs (lincRNAs) are lncRNAspresent in the intergenic regions and have an important role in the maintenance of a pluripotent state of cells. Study on mice embryonic stem cells revealed that knockdown of lincRNA gene effects on gene regulation [85].

\section{Evolutionary perspective}

RNA has evolved earlier than DNA as a genetic material. The former has served as a temporary storage of genetic information [20], while the latter confers structural stability to RNA as a double-strandedmolecule and is able to store genetic information [20, 74]. However, RNA retained the diverse array of functionality in deciphering the genetic scripts and encoding proteins.

Iyer and colleagues estimated that more than 10,000 lncRNA coding genes are present in the human genome and about 60,000 lncRNAs are transcribed in all types of cells [40]. Whole genome alignment of human and mouse IncRNAs showed that the exonic region of IncRNAs evolved at a slower rate as compared to those from the intergenic region and introns of protein coding sequence. This indicates that some lncRNAs may be non-functional or their function can overcome precise sequence constraints [36]. The degree of nucleotide conservation of lncRNAs can be examined on inter-specific or intra-specific levels[31].

Bioinformatics support is now available to study evolutionary perspectives of lncRNAs. The software named "slncky" has recently been designed for the evolutionary analysis of lncRNA in mammals. It uses RNA sequencing data, removes the overlapping transcripts of 
annotated and unannotated protein-coding genes present in same species and aligns identified transcripts. The remaining set of fragments are characteristically conservedandlong non-coding transcripts, hence these areidentified as lncRNAs [10].

\section{Biological role of IncRNAs: Association with diseases}

The lncRNAs play a versatile role, as discussed above, in various biological processes and disease states by interacting with DNA, RNA and other transcriptional molecules. They have a role in histone modification, chromatin remodeling, gene expression regulation, gene silencing, DNA methylation, heat shock response and embryogenesis [3]. The mutation in IncRNA is associated with various diseases including virus infection, cancer, and neurodegenerative disorders. Any dysregulation in lncRNAs influences the normal cellular functions including cell proliferation, resistance to apoptosis, induction of angiogenesis and evasion of tumor suppressors [28] (Fig. 2). Knockdown of some lncRNAsis responsible for the change in gene expression due to loss of pluripotency[86] of embryonic cells. Till date, very sparse research has been conducted on lncRNAs. Divergent lncRNAs has been adumbrated in Table 1 with their roles in normal physiological and pathological conditions in different mammals.

\section{The role of IncRNA in epigenetics}

In the early 1990s it was discovered that lncRNAs are involved in epigenetic gene regulation (viz. H19 and Xist) [111]. In this section the IncRNA genes viz. Xist and H19 that are associated with epigenetic regulation of pathophysiological conditions are discussed.

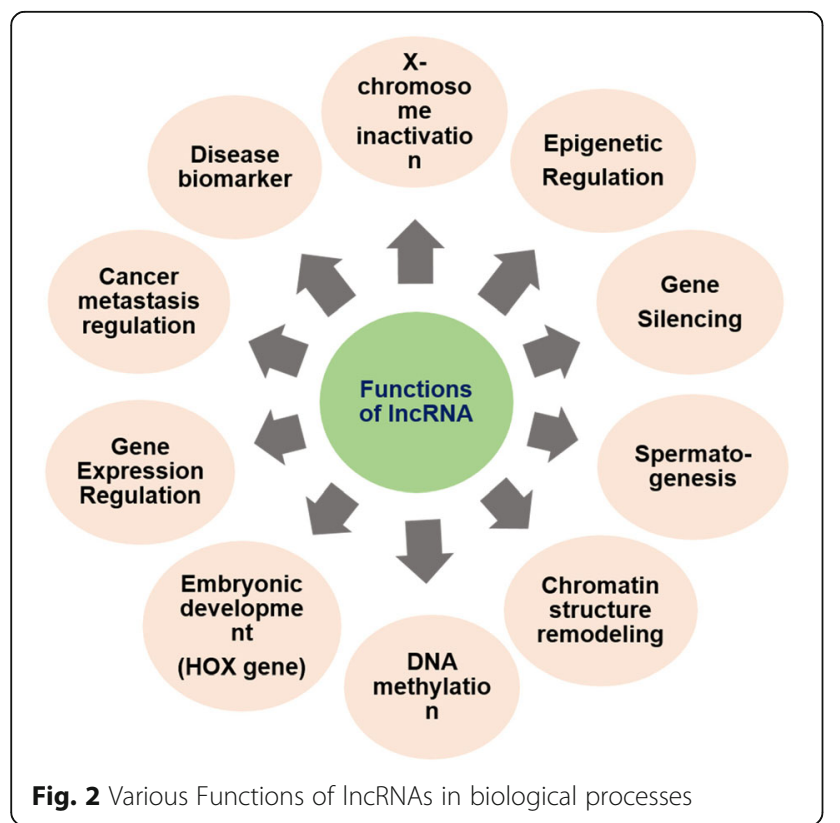

Xist

One of the X-chromosomes in female mammals gets randomly inactivated (heterochromatinizedfacultative) during early embryonic stages to ensure dosage compensation in females with regard to the hemizygotic males harboring a single copy of those $\mathrm{X}$-linked genes. $\mathrm{X}$-inactive specific transcript (Xist), a $17 \mathrm{~Kb}$ gene located on mammalian $\mathrm{X}$-chromosome, is an example of lncRNA which is responsible for $\mathrm{X}$-chromosome inactivation in eutherian mammals. The regulation of cis- $\mathrm{X}$ inactivation is initiated by coating the X-chromosome and engaging polycomb repressive 2 (PRC2) complex to specific sites. This results in histone H3 lysine K27 trimethylation (H3K27me3) and $\mathrm{X}$-linked inactivation [111].

\section{H19}

This lncRNA gene is located at Beckwith-Wiedemann Syndrome (BWS) locus in humans [68]. The lncRNA H19, not only regulates maternal imprinting during embryogenesis but also binds to methyl-CpG-binding-domain protein 1 (MBD1) and recruits histone-lysine-methyltransferase-containing complexes to place repressive H3K9 methylation marks on target imprinted loci [88]. HuR, an RNA binding protein, negatively regulates the expression of miR-675 by binding with $\mathrm{H} 19$ and is responsible for decreased cell proliferation and limited placental growth before birth [45].

\section{Genomic imprinting}

Genomic imprinting is an epigenetic process by which a specific gene is expressed in a monoallelic manner depending on the parent of origin [100]. The lncRNAs were also found to be involved in some imprinting processes. In the process of uniparental gene expression, the lncRNA recruits DNA methyltransferases instead of PRC2 for histone modification and DNA methylation [67]. The orthologs of some human lncRNAs (Airn, H19, Kcnq1ot1, Meg3, and Meg8) have been identified in 24 different species that are responsible for controlling genomic imprinting [44]. The lncRNAsAirn and Kcnq1 opposite transcript 1 (Kcnq1ot1)/ long QT intronic transcript 1(L1 T1) are responsible for suppression of paternally inherited genes [103]. The clusters of imprinted genes are found to be conserved containing at least one IncRNA gene. These IncRNAs form a cluster with DNA duplex to produce a triplex structure [99]. Insulin-like growth factor-2 (Igf2) and insulin-like growth factor-2 receptor (Igf2r) are examples of maternally and paternally imprinted genes, respectively, for embryonic growth control [44]. Mental disorder or incidence of cancer has been associated with dysregulated imprinting of such genes [42].

\section{Cancer}

The study of lncRNAs till date inferences that whether these molecules are associated and involved in various 
Table 1 List of some Long non-coding RNAs and their role in different tissues

\begin{tabular}{|c|c|c|c|c|}
\hline SN & Type or Family & Target Tissue & Role & Reference \\
\hline 1 & Heat shock RNA1 (HSR1) & Various tissues & $\begin{array}{l}\text { - stimulates trimerization of heat-shock factor } \\
1 \text { (HSF1)with eukaryotic translation elongation } \\
\text { factor } 1 \text { A }\end{array}$ & [91] \\
\hline 2 & $\begin{array}{l}\text { Meiotic recombination hot } \\
\text { spot1 locus (Mrhl) }\end{array}$ & Located in nucleus & - Regulate spermatogenesis & [23] \\
\hline 3 & HongrES2 & $\begin{array}{l}\text { Expressed specifically } \\
\text { in the cauda-epididymis }\end{array}$ & $\begin{array}{l}\text { - The transcript mil-HongrES2 inhibits } \\
\text { expression of an epididymis-specific protein CES7 } \\
\text { and its cholesterol esterase activity; } \\
\text { - its overexpression results in retarded sperm } \\
\text { capacitation }\end{array}$ & [70] \\
\hline 4 & Testis-specific X-linked (Tsx) & $\begin{array}{l}\text { Expressed in pachytene } \\
\text { spermatocytes }\end{array}$ & - regulatory role in germline meiotic division & [1] \\
\hline 5 & Dmrt1-related gene (Dmr) & Testis-specific & $\begin{array}{l}\text { - essential transcription factor that } \\
\text { promotesspermatogonial development by } \\
\text { up-regulating } \\
\text { Sohlh1 (Spermatogenesis and Oogenesis Specific } \\
\text { Basic Helix-Loop-Helix 1); } \\
\text { - prevents premature meiosis in spermatogonia } \\
\text { by repressing Stra8 (Gene stimulated by retinoic acid 8) }\end{array}$ & [76] \\
\hline 6 & $\begin{array}{l}\text { Homeobox antisense } \\
\text { intergenic RNA (HOTAIR) }\end{array}$ & $\begin{array}{l}\text { Gastric adenocarcinoma } \\
\text { tissues, Lung, Breast, Kidney }\end{array}$ & $\begin{array}{l}\text { - Promotes cancer cell migration, invasion, and } \\
\text { metastasis } \\
\text { - Increased expression may affect genomic } \\
\text { relocalization of the polycomb repressive complex 2; } \\
\text { - Can enhance trimethylation of H3K27; } \\
\text { - biomarker for poor prognosis in colorectal cancer }\end{array}$ & {$[32,48]$} \\
\hline 7 & $\begin{array}{l}\text { Metastasis-associated lung } \\
\text { adenocarcinoma transcript } 1 \text { (MALAT1) }\end{array}$ & Lung, pancreas & $\begin{array}{l}\text { - Promotes cancer cell migration, invasion, and metastasis } \\
\text { - Knockdown of MALAT1 (in HCC cell line) } \\
\text { demonstrated amarked reduction in tumor progression. } \\
\text { So it can be used as negative prognostic biomarker }\end{array}$ & [29] \\
\hline 8 & Maternally Expressed Gene (MEG3) & $\begin{array}{l}\text { Glioma cells, bladder, } \\
\text { gastric tissues }\end{array}$ & $\begin{array}{l}\text { - Tumor suppressive } \\
\text { - Due to down-regulated expression in various tumor } \\
\text { conditions including meningioma and glioma, it acts } \\
\text { as tumor suppressor }\end{array}$ & [104] \\
\hline 9 & Taurineupregulated gene 1 (TUG1) & Osteosarcoma tissue & $\begin{array}{l}\text { - Tumor suppressive } \\
\text { - Inhibit apoptosis }\end{array}$ & [115] \\
\hline 10 & GAS5 & $\begin{array}{l}\text { Lung, breast, colorectal, } \\
\text { kidney, prostate }\end{array}$ & - Induces apoptosis and suppresses miR-21 expression & [92] \\
\hline 11 & $\begin{array}{l}\text { BRAF Activated Noncoding } \\
\text { RNA (BANCR) }\end{array}$ & Lung & - Tumor suppressive & [96] \\
\hline 12 & $\mathrm{H} 19$ & Lung & $\begin{array}{l}\text { - Tumor suppressor gene } \\
\text { - Higher H19 expression due to demethylation of promoter } \\
\text { region results in induction of lung cancer }\end{array}$ & {$[12,77]$} \\
\hline
\end{tabular}

biological processes but their dysregulation can develop cancer. Metastasis-associated lung adenocarcinoma transcript 1 (Malat1) is a lncRNA that is involved in localization of splicing factors serine/arginine to the nuclear speckles. These lncRNAs control the alternative splicing of various mRNA precursors and play important role in the pathogenesis resulting from metastasis and cell invasion [41]. It can affect regulation of cytoskeletal and extracellular matrix genes at transcriptional and post-transcriptional levels [98]. Some transcripts of lncRNA including Xist and Kcnq1ot1 are also involved in dosage compensation [24]. In another report, it has been mentioned that the apoptosis of breast cancer cells can be inhibited by plasmacytoma variant translocation 1 gene (PVT1) [101, 102, 105].
HOTAIR lncRNA can promote cancer metastasis in the chromatin state of cancer cells through epigenetic variations [39]. The up-regulation of HOTAIR could be associated with poor or failed prognosis, in various types of cancers including breast, liver, gastrointestinal and pancreatic cancers $[27,107]$. Steroid receptor RNA activator (SRA) is a lncRNA that is linked to breast cancer with highly conserved helices and loops [72]. PCAT-1 is another lncRNA involved in the stimulation of cell proliferation [83]. Prostate cancer has been associated with over-expression of long intergenic non-protein coding RNA gene SCHLAP1 (SWI/SNF Complex Antagonist Associated with Prostate Cancer 1) [89]. Up-regulation of TUG1 promotes proliferation and migration of 
esophageal squamous cell carcinoma while its downregulation inhibits osteosarcoma cell proliferation and promotes apoptosis [94].

\section{Autoimmune disease}

An abnormal immune response to the normal body due to complex environmental profile results in the development of autoimmune disease(s). Research reports show that lncRNAs contribute to the development of certain autoimmune diseases in human and mice, in a similar manner of some of the miRNAs that are found to be essential for normal immune response and to prevent autoimmune diseases [93]. Autoimmune diseases caused by a minute change in gene regulation or cells related to immune response (B cells, $T$ cells etc) [110] can be detected from the regulation process of IncRNAs. The up or down-regulation of some lncRNAs has also been detected to be associated with various autoimmune diseases. For example, the up-regulation of GAS5 is associated with sclerosis and tuberculosis whereas down-regulation was detected in rheumatoid arthritis [65]. Under homeostatic conditions, lnc13 is known to repress the expression of inflammation-related genes [7].

\section{Differentiation and regulation of spermatogonial stem cells (SSC)}

Another role of IncRNA has been detected in sexual identities via regulating the expression of sex determination genes from fly to mice [90]. The role of lncRNAs in differentiation and regulation of SSC self-renewal has been reported in glial cell-derived neurotrophic factor (GDNF) [58, 59]. Some lncRNAs are also involved in regulation of male reproduction. In vitro study in mouse showed that AK015322 IncRNA promotes proliferation of spermatogonial stem cell line C18-4 [37].

\section{Role in spermatogenesis}

The whole genome expression profile of spermatogenesisrelated lncRNAs has revealed that testis is one of the highly abundant lncRNA containing tissue. The expression of testis-specific lncRNAs, IncRNA-Tcam1 and lncRNA-HSVIII has been identified in spermatocyte stages [114]. TUG1 is a long, intergenic gene that is up-regulated in various human cell lines and tumors.

\section{Other physiological functions}

Meiotic recombination hot spot locus (Mrhl) is a 2.4-kb mono-exonic IncRNA sited in the nucleus of mouse chromosome 8 which play a major role in the regulation of spermatogenesis. Despite that HongrES2 (in rat), Testis-specific X-linked (Tsx) (expressed in pachytene spermatocytes), the Dmrt1-related gene (Dmr) (testisspecific lncRNA) are some other lncRNA identified in different species and tissues [62]. During the embryonic development of mouse, some lncRNA including AB06 3319, AK003491, and AK044800 have been reported to be abundantly expressed in brain, muscle, liver, lung and neuroendocrine tissues [8].

\section{The IncRNAs as biomarkers for disease control}

The lncRNAs are involved in various biological and pathological processes including neurogenesis, oncogenesis and stem cell pluripotency[103]. Various lncRNAsare known to possess tumor suppressive and oncogenic roles thus can act as a biomarker for disease diagnosis. At present, there are limited reports on IncRNAs as validated biomarkers. The altered lncRNA expression pattern in uterine corpus endometrial carcinoma (UCEC) suggested that lncRNAs can act as predictive biomarkers for a high-risk patient with endometrial carcinoma [101, $102,105]$. Highly up-regulated in liver cancer (HULC) has been found to act as a diagnostic marker for hepatocellular cancer [2]. The level of PCAT1 in urine can help in detection of poor prognosis prostate cancer patients [41]. HOTAIR, MALAT1, microvascular invasion of HCC (MVIH), H19 etc. are some other examples of lncRNA that can be used as biomarkers. Alternatively, DD3 can be used as a negative prognostic biomarker in prostate cancer [13]. The lncRNAs can also be used as biomarkers for sepsis detection in patients [22]. They are also involved in the pathogenesis of ovarian cancer [84].

\section{Databases for IncRNAs}

The IncRNA-pool in the genome can be bio-computationally predicted, identified and finally validated through various experimental and computational methods including microarray, SAGE, RNA-immunoprecipitation RNA-Seq, in silico identification of open reading frame (ORF) and by machine learning techniques [63]. The data obtained from the de novo analysis is further organized through the specific database. The database can maintain, archive or retrieve the information related to lncRNAs. This can further annotate the features and will provide the interactions and functions with different molecules in systems biology. To study the structure and function of different lncRNAs, various online databases have been identified to date. Some of them are mentioned here with some descriptions. lncRNAdb (http://www.lncRNAdb.org/) provides detailed information about functional lncRNAs[9]. The sequence and structure information of human lncRNA is available through LNCipedia (http://www.lncipedia.org) [112]. ChIPBase (http://rna.sysu.edu.cn/chipbase/) database helps to study transcription factor binding site and motifs and provides the decoded information of transcriptional regulatory network [18]. The study of the expression of human and mouse lncRNA is available 
through a chip-based strategy of NRED (http://nred. matticklab.com/cgi-bin/ncrnadb.pl) [97].

\section{Conclusion}

Significant research endeavors are being exercised on non-coding RNAs (ncRNAs)with an aim to study their role in biological processes, apply ncRNAs as biomarkers and to unveil the systems biology. A decade ago, miRNAs were the most popular ncRNA for scientific research and study but now the other class of ncRNAs, lncRNAs is also on the high priority to unveil their role in disease development and control process. The available literature shows their important contribution in metastasis and thus can be a target in cancer therapy. They can be used as disease biomarker and to explore systems biology. Last but not the least, the transcription machinery of eukaryotic cells is partially depicted by the major players like coding and non-coding RNAs. Recent studies at Buratowski laboratory of Harvand Medical School (https://buratowski.hms. harvard.edu/) has postulated and experimentally validated that the transcription process itself can modify the chromatin that underscores the importance of several factors other than noncoding RNAs like lncRNA [46]. In depth studies are warranted to unveil the complete systems biology involved in modulation of gene expression in eukaryotic cells.

\section{Acknowledgments}

The laboratory facilities provided by GADVASU, Ludhiana are sincerely acknowledged.

\section{Funding}

The authors are thankful to the Department of Biotechnology (DBT), Government of India (Project no. AAB-009) for providing funds.

\section{Authors' contributions}

JKD Data collection and Manuscript writing; RSS. RV and JSA Manuscript editing; CSM Hypothesizing and Planning the work, Data collection and Manuscript writing. All authors read and approved the final manuscript.

\section{Ethics approval and consent to participate}

Not applicable.

\section{Consent for publication}

Not applicable.

\section{Competing interests}

The authors declare that they have no competing interests.

\section{Publisher's Note}

Springer Nature remains neutral with regard to jurisdictional claims in published maps and institutional affiliations.

Received: 23 August 2018 Accepted: 5 October 2018

Published online: 25 October 2018

\section{References}

1. Anguera MC, Ma W, Clift D, Namekawa S, Kelleher RJ, Lee JT. Tsxproduces a long noncoding RNA and has general functions in the germline, stem cells,and brain. PLoS Genet. 2011;7:e1002248. https://doi.org/10.1371/journal. pgen.1002248.

2. Ayers D. Long noncoding RNAs: novel emergent biomarkers for Cancer diagnostics. J Cancer Res Treat. 2013;1 (2):31-5.
3. Birney E, Stamatoyannopoulos JA, Dutta A, Guigo R, Gingeras TR, Margulies $\mathrm{EH}$, Weng $\mathrm{Z}$, et al. Identification and analysis of functional elements in $1 \%$ of the human genome by the ENCODE pilot project. Nature 2007;447:799-816.

4. Bolha L, Ravnik-Glavač M, Glavač D. Long noncoding RNAs as biomarkers in Cancer. Dis Markers. 2017;2017:7243968. https://doi.org/10.1155/2017/ 7243968.

5. Cao J. The functional role of long non-coding RNAs and epigenetics. Biol Proced Online. 2014;16:11.

6. Carrieri C, Cimatti L, Biagioli M, Beugnet A, Zucchelli S, Fedele S, Pesce E, Ferrer I, Collavin L, Santoro C, et al. Long noncoding antisense RNA controls Uchl1 translation through an embedded SINEB2 repeat. Nature. 2012:491:454-7.

7. Castellanos-Rubio A, Fernandez-Jimenez N, Kratchmarov R, Luo X, Bhagat G, Green PH, Schneider R, Kiledjian M, Bilbao JR, Ghosh S. A long noncoding RNA associatedwith susceptibility to celiac disease. Science. 2016;352:91-5.

8. Chen B, Yu M, Chang Q, et al. Mdig de-represses H19 large intergenic noncoding RNA (lincRNA) by down-regulating H3K9me3 and heterochromatin. Oncotarget. 2013a;4:1427-37.

9. Chen G, Wang Z, Wang D, Qiu C, Liu M, Chen X, et al. The IncRNA disease: a database for long-noncoding RNA-associated diseases. Nucleic Acids Res. 2013b:41:D983-6.

10. Chen J, Shishkin AA, Zhu X, Kadri S, Maza I, Guttman M, Hanna JH, et al. Evolutionary analysis across mammals reveals distinct classes of long noncoding RNAs. Genome Biol. 2016;17:19. https://doi.org/10.1186/s13059016-0880-9.

11. Chen W, Bocker W, Brosius J, Tiedge H. Expression of neural BC200 RNA in human tumours. J Pathol. 1997;183(3):345-51.

12. Chen Z, Jia S, Li D, Cai J, Tu J, Geng B, Guan Y, Cui Q, Yang J. Silencing of long noncoding RNA AK139328 attenuates ischemia/reperfusion injury in mouse livers. PLoS One. 2013:8(11):e80817.

13. Dai Y, Liang Z, Li Y, Li C, Chen L. Circulating long noncoding RNAs as potential biomarkers of Sepsis: a preliminary study. Genet Test Mol Biomarkers. 2017. https://doi.org/10.1089/gtmb.2017.0061.

14. Dempsey JL, Cui JY. Long noncoding RNAs: a novel paradigm for toxicology. Toxicol Sci. 2017;155(1):1-21.

15. Derrien $T$, Johnson $\mathrm{R}$, Bussotti $\mathrm{G}$, Tanzer A, Diebali S, Tilgner $\mathrm{H}$ et al. The GENCODE v7 catalog of human long noncoding RNAs: analysis of their gene structure, evolution and expression. Genome Research. 2012;22:1775-89.

16. Dinger ME, Amaral PP, Mercer TR, Pang KC, Bruce SJ, et al. Long noncoding RNAs in mouse embryonic stem cell pluripotency and differentiation. Genome Res. 2008;18:1433-45.

17. Dinger ME, Gascoigne DK, Mattick JS. The evolution of RNAs with multiple functions. Biochimie. 2011:93:2013e2018.

18. Dinger ME, Pang KC, Mercer TR, Crowe ML, Grimmond SM, Mattick JS. NRED: a database of long noncoding RNA expression. Nucleic Acids Res. 2009;37:D122-6.

19. Fang Y, Fullwood MJ. Roles, functions, and mechanisms of long noncoding RNAs in Cancer. Genomics Proteomics Bioinformatics. 2016;14:42-54.

20. Forterre P. Origin of DNA and DNA genomes. Curr Opin Microbiol. 2002:5:525-32.

21. Friedlander MR, Lizano E, Houben AJS, Bezdan D, Báñez-Coronel M, Kudla G, Mateu-Huertas E, Kagerbauer B, González J, et al. Evidence for the biogenesis of more than 1,000 novel human microRNAs. Genome Biol. 2014;15:R57.

22. Fu LL, Li CJ, XU Y, Li LY, Zhou X, Li DD, Chen SX, et al. Role of IncRNAs as novel biomarkers and therapeutic targets in ovarian Cancer. Crit Rev Eukaryot Gene Expr. 2017;27(2):183-95. https://doi.org/10.1615/ CritRevEukaryotGeneExpr.2017019244.

23. Ganesan G, Rao SM. A novel noncoding RNA processed by Drosha is restricted to the nucleus in the mouse. RNA. 2008;14:1399-410. https://doi. org/10.1261/rna.838308.

24. Gardini A, Shiekhattar R. The many faces of long noncoding RNAs. FEBS J. 2015;282(9):1647-57. https://doi.org/10.1111/febs.13101.

25. Gomes $A Q$, Nolasco S, Soares H. Noncoding RNAs: multi-tasking molecules in the cell. Int J Mol Sci. 2013;14:16010-39. https://doi.org/10.3390/ ijms140816010.

26. Gonzalez I, Munita R, Agirre E, Dittmer TA, Gysling K, Misteli T, Luco RF. A IncRNA regulates alternative splicing via the establishment of a splicingspecific chromatin signature. Nat Struct Mol Biol. 2015;22:370-6.

27. Gupta RA, Shah N, Wang KC, Kim J, Horlings HM, Wong DJ, Tsai MC, et al. Long noncoding RNA HOTAIR reprograms chromatin state to promote cancer metastasis. Nature. 2010;464:1071-6. 
28. Gutschner T, Diederichs $\mathrm{S}$. The hallmarks of cancer: a long noncoding RNA point of view. RNA Biol. 2012;9:703-19.

29. Gutschner T, Hämmerle M, Eissmann M, Hsu J, Kim Y, Hung G, et al. The noncoding RNA MALAT1 is a critical regulator of the metastasis phenotype of lung cancer cells. Cancer Res. 2013;73(3):1180-9.

30. Guttman M, Russell P, Ingolia NT, Weissman JX, Lander ES. Ribosome profiling provides evidence that large noncoding RNAs do not encode proteins. Cell. 2013;154:240e251.

31. Haerty W, Ponting CP. Mutations within IncRNAs are effectively selected against in fruitfly but not in human. Genome Biol. 2013;14:R49.

32. Hajjari M, Behmanesh M, Sadeghizadeh M, Zeinoddini M. Up-regulation of HOTAIR long noncoding RNA in human gastric adenocarcinoma tissues. Med Oncol Northwood Lond Engl. 2013;30(3):670.

33. Han P, Chang C-P. Long noncoding RNA and chromatin remodeling. RNA Biol. 2015:12(10):1094-8.

34. Hangauer MJ, Vaughn IW, McManus MT. Pervasive transcription of the human genome produces thousands of previously unidentified long intergenic noncoding RNAs. PLoS Genet. 2013;9:e1003569.

35. Hawkins PG, Morris KV. Transcriptional regulation of Oct4 by a long noncoding RNA antisense to Oct4-pseudogene 5. Transcr. 2010;1(3):165-75.

36. Hezroni H, Koppstein D, Schwart MG, Avrutin A, Bartel DP, Ulitsky I. Principles of long noncoding RNA evolution derived from a direct comparison of transcriptomes in 17 species. Cell Rep. 2015;11(7):1110-22. https://doi.org/10.1016/j.celrep.2015.04.023.

37. Hu K, Zhang J, The LM. IncRNA AK015322 promotes proliferation of spermatogonial stem cell C18-4 by acting as a decoy for microRNA-19b-3p. In Vitro Cell Dev Biol Anim. 2017;53(3):277-84. https://doi.org/10.1007/ s11626-016-0102-5.

38. Hung $T$, Wang $Y$, Lin MF, Koegel AK, KotakeY GGD, Horlings HM, et al. Extensive and coordinated transcription of noncoding sRNAs within cellcycle promoters. Nat Genet. 2011;43(7):621-9.

39. Ishibashi M, Kogo R, Shibata K, Sawada G, Takahashi Y, Kurashige J, Akiyoshi $S$, et al. Clinical significance of the expression of long noncoding RNA HOTAIR in primary hepatocellular carcinoma. Oncol Rep. 2013;29:946-50.

40. Iyer MK, Niknafs YS, Malik R, Singhal U, Sahu A, Hosono Y, Barrette TR, et al. The landscape of long noncoding RNAs in the human transcriptome. Nat Genet. 2015:47:199-208.

41. Jalali S, Jayaraj GG, Scaria V. Integrative transcriptome analysis suggests processing of a subset of long noncoding RNAs to small RNAs. Biol Direct. 2012;7:25

42. Jelinic P, Shaw P. Loss of imprinting and cancer. J Pathol. 2007;211:261-8.

43. Juan V, Crain C, Wilson C. Evidence for evolutionarily conserved secondary structure in the H19 tumor suppressor RNA. Nucleic Acids Res. 2000;28: $1221-7$

44. Kanduri C. Long noncoding RNAs: lessons from genomic imprinting. Biochim Biophys Acta (BBA) Gene Regulatory Mechanisms. 2016;1859(1): 102-11

45. Keniry A, Oxley D, Monnier P, Kyba M, Dandolo L, Smits G, Reik W. The H19 lincRNA is a developmental reservoir of miR-675 that suppresses growth and Igf1r. Nat Cell Biol. 2012;14(7):659-65.

46. Kim JH, Lee BB, Oh YM, Zhu C, Steinmetz LM, Lee Y, Kim WK, Lee SB, Buratowski S, Kim T. Modulation of mRNA and IncRNA expression dynamics by the Set2-Rpd3S pathway. Nat Commun. 2016;7:13534. https://doi.org/10. 1038/ncomms13534.

47. Kiss T. Biogenesis of small nuclear RNPs. J Cell Sci. 2004;117:5949-51.

48. Kogo R, Shimamura T, Mimori K, Kawahara K, Imoto S, Sudo T, et al. Long noncoding RNA HOTAIR regulates polycomb-dependent chromatin modification and is associated with poor prognosis in colorectal cancers. Cancer Res. 2011;71(20):6320-6.

49. Kono T, Sotomaru Y, Katsuzawa Y, Dandolo L. Mouse parthenogenetic embryos with monoallelic H19 expression can develop to day 17.5 of gestation. Dev Biol. 2002;243:294-300

50. Kung JTY, Colognori D, Lee JT. Long noncoding RNAs: past, present, and future. Genetics. 2013;193:651-69.

51. Lapidot M, Pilpel Y. Genome-wide natural antisense transcription: coupling its regulation to its different regulatory mechanisms. EMBO Rep. 2006;7: $1216-22$.

52. Johnsson P, Lipovich L, Grandér D, Morris KV. Evolutionary conservation of long noncoding RNAs; sequence, structure, function. Biochim Biophys Acta. 2014;1840:1063-71. https://doi.org/10.1016/j.bbagen.2013.10.035.
53. Quinn JJ, Zhang QC, Georgiev P, llik IA, Akhtar A, Chang HY. Rapid evolutionary turnover underlies conserved IncRNA-genome interactions. Genes Dev. 2016;30(2):191-207. https://doi.org/10.1101/gad.272187.115.

54. Guttman M, Amit I, Garber M, French C, Lin MF, Feldser D, Huarte M, Zuk O, Carey BW, Cassady JP, Cabili MN, Jaenisch R, Mikkelsen TS, Jacks T, Hacohen N, Bernstein BE, Kellis M, Regev A, Rinn JL, Lander ES. Chromatin signature reveals over a thousand highly conserved large non-coding RNAs in mammals. Nature. 2009;458(7235):223-7. https://doi.org/10.1038/ nature07672.

55. Ponjavic J, Ponting CP, Lunter G. Functionality or transcriptional noise? Evidence for selection within long noncoding RNAs. Genome Res. 2007;17: 556-65.

56. Pang KC, Frith MC, Mattick JS. Rapid evolution of noncoding RNAs: lack of conservation does not mean lack of function. Trends Genet. 2006;22:1-5.

57. Leighton PA, Ingram RS, Eggenschwiler J, Efstratiadis A, Tilghman SM. Disruption of imprinting caused by deletion of the $\mathrm{H} 19$ gene region in mice. Nature. 1995:375(6526):34-9.

58. Li L, Wang M, Wang M, Wu X, Geng L, Xue $Y$, Wei X, Jia $Y$, Wu X. A long noncoding RNA interacts with Gfral and maintains the survival of mouse spermatogonial stem cells. Cell Death Dis. 2016a;7:e2140.

59. Li R, Zhu H, Luo Y. Understanding the functions of long noncoding RNAs through their higher-order structures. Int J Mol Sci. 2016b;17:702. https://doi. org/10.3390/ijms17050702.

60. Losko M, Kotlinowski J, Jura J. Long Noncoding RNAs in Metabolic Syndrome Related Disorders. Mediators of Inflammation. 2016;2016:1-12. https://doi.org/10.1155/2016/5365209.

61. Louro R, Smirnova AS, Verjovski-Almeida S. Long intronic noncoding RNA transcription: expression noise or expression choice? Genomics. 2008; 93(2009):291-8.

62. Luk AC-S, Chan W-Y, Rennert OM, Lee T-L. Long noncoding RNAs in spermatogenesis: insights from recent high-throughput transcriptome studies. Reproduction. 2014;147:R131-41.

63. Ma H, Hao Y, Dong X, Gong Q, Chen J, Zhang J, Tian W. Molecular mechanisms and function prediction of long noncoding RNA. Sci World J. 2012;2012:1-11. https://doi.org/10.1100/2012/541786

64. Mariner PD, Walters RD, Espinoza CA, Drullinger LF, Wagner SD, Kugel JF, Goodrich JA. HumanAlu RNA is a modular transacting repressor of mRNA transcription during heat shock. Mol Cell. 2008;29:499-509.

65. Mayama T, Marr AK, Kino T. Differential expression of glucocorticoid receptor noncoding RNA repressorGas5 in autoimmune and inflammatory diseases. HormMetab Res. 2016;48:550-7.

66. Mercer TR, Dinger ME, Sunkin SM, Mehler MF, Mattick JS. Specific expression of long noncoding RNAs in the mouse brain. Proc Natl Acad Sci U S A. 2008;105:716-21.

67. Mohammad F, Mondal T, Guseva N, Pandey GK, Kanduri C. Kenq1 ot1 noncoding RNA mediates transcriptional gene silencing by interacting with Dnmt1. Development (Cambridge, England). 2010;137(15):2493-9. https:// doi.org/10.1242/dev.048181.

68. Monnier P, Martineta C, Pontisc J, Stanchevad I, Ait-Si-Alic S, Dandoloa L. H19 IncRNA controls gene expression of the imprinted gene network by recruiting MBD1. PNAS. 2013;110(51):20693-8.

69. Mukhopadhyay CS, Singh J. MicroRNAs: Basics, Implications,and Modulation in Improving Disease Resistance. DBT Sponsored Short Term Training Course on Molecular Tools and Bioinformatics Approaches for Livestock Genome Analysis, delivered on 13th September' 2014 at Central Institute for Research on Cattle, Grass Farm Road, Meerut, UP, organized during 10th to 30th September' 2014;67-73

70. Ni MJ, Hu ZH, Liu Q, Liu MF, Lu MH, Zhang JS, Zhang L, Zhang YL. Identification and characterization of a novel noncoding RNA involved in sperm maturation. PLoS One. 2011;6:e26053. https://doi.org/10.1371/journal. pone.0026053.

71. Niu D-K, Jiang L. Can ENCODE tell us how much junk DNA we carry in our genome? Biochem Biophys Res Commun. 2013;430:1340-3.

72. Novikova IV, Hennelly SP, Sanbonmatsu KY. Structural architecture of the human long noncoding RNA, steroid receptor RNA activator. Nucleic Acids Res. 2012;40:5034-51.

73. Ohno S. So much "junk" DNA in our genome. Brookhaven Symp Biol. 1972; 23:366-70.

74. Olsen GJ, Woese CR. Archaeal genomics: an overview. Cell. 1997;89:991-4.

75. Orgel LE, Crick FH. Selfish DNA: the ultimate parasite. Nature. 1980; 284(5757):604-7. https://doi.org/10.1038/284604a0. 
76. Ottolenghi C, Veitia R, Barbieri M, Fellous M, McElreavey $K$. The human doublesex-related gene, DMRT2, is homologous to a gene involved in somitogenesis and encodes a potential bicistronic transcript. Genomics. 2000;64:179-86. https://doi.org/10.1006/geno.2000.6120.

77. Palazzo AF, Lee ES. Non-coding RNA: what is functional and what is junk? Front Genet. 2015;6:2. https://doi.org/10.3389/fgene.2015.00002.

78. Paraskevopoulou MD, Hatzigeorgiou AG. Analyzing miRNA-the IncRNA interactions- Long Non-Coding RNAs. Methods Mol Biol. 2016;1402:271-86. https://doi.org/10.1007/978-1-4939-3378-5_21.

79. Patil VS, Zhou R, Rana TM. Gene regulation by noncoding RNAs. Crit Rev Biochem Mol Biol. 2014;49(1):16-32. https://doi.org/10.3109/10409238.2013. 844092.

80. Peschansky VJ, Wahlestedt C. Noncoding RNAs as direct and indirect modulators of epigenetic regulation. Epigenetics. 2014;9:3-12 doi.org/10. 4161/epi.27473.

81. Ponting $\mathrm{CP}$, Oliver PL, Reik W. Evolution and functions of long noncoding RNAs. Cell. 2009;136:629-41.

82. Prensner JR, Chinnaiyan AM. The emergence of IncRNAs in cancer biology. Cancer Discovery. 2011;1(5):391-407.

83. Prensner JR, lyer MK, Balbin OA, Dhanasekaran SM, Cao Q, et al. Transcriptome sequencing across a prostate cancer cohort identifies PCAT1 , an unannotated lincRNA implicated in disease progression. Nat Biotechnol. 2011;29:742-9.

84. Quek XC, Thomson DW, Maag JL, Bartonicek N, Signal B, Clark MB, et al. IncRNAdb v2.0: expanding the reference database for functional longnoncoding RNAs. Nucleic Acids Res. 2015;43:D168-73.

85. Rinn JL, Chang HY. Genome regulation by long noncoding RNAs. Annu Rev Biochem. 2012;81:145-66. https://doi.org/10.1146/annurev-biochem051410-092902.

86. Roberts TC, Morris KV, Wood MJA. The role of long non-coding RNAs in neurodevelopment, brain function and neurological disease. Phil Trans $R$ Soc B. 2014;369:20130507 https://doi.org/10.1098/rstb.2013.0507.

87. Romero-Barrios N, Legascue MF, Benhamed M, Ariel F, Crespi M. Splicing regulation by long noncoding RNAs. Nucleic Acids Res. 2018;46(5):2169-84 https://doi.org/10.1093/nar/gky095.

88. Satpathy AT, Chang HY. Long noncoding RNA in hematopoiesis and immunity. Immunity. 2015;42:792-804 https://doi.org/10.1016/j.immuni.2015. 05.004.

89. Schmitt AM, Chang HY. Long noncoding RNAs in Cancer pathways. Cancer Cell. 2016;29(4):452-63.

90. Schutt C, Nothiger R. Structure, function and evolution of sex-determining systems in dipteran insects. Development (Cambridge, England). 2000; 127(4):667-77.

91. Shamovsky I, Ivannikov M, Kandel ES, Gershon D, Nudler E. RNA-mediated response to heat shock in mammalian cells. Nature. 2006;440:556-60.

92. Shi $X$, Sun $M$, Liu $H$, Yao $Y$, Kong $R$, Chen F, Song $Y$. A critical role for the long noncoding RNA GAS5 in proliferation and apoptosis in nonsmallcell lung cancer. MolCarcinog. 2015;54(1):E1-E12. https://doi.org/10. 1002/mc.22120

93. Singh J, Mukhopadhyay CS, Dhanoa JK, Arora JS, Kaur S. miRNA repertoire of bubaline PBMC obtained from disease tolerant vis-a-vis susceptible buffaloes. Poster presentation (Poster No. AH-14) and abstract publication (Abstract No. ASC2015ABS1418031523) in XII Agricultural Science Congress and Silver Jubilee of National Academy of Agricultural Science, India, organized during 3-6th February 2015, at National Dairy Research Institute, Karnal; pp. 180.

94. Sun J, Ding C, Yang Z, Liu T, Zhang X, Zhao C, Wang J. The long noncoding RNA TUG1 indicates a poor prognosis for colorectal cancer and promotes metastasis by affecting epithelial-mesenchymal transition. J Transl Med. 2016;14:42. https://doi.org/10.1186/s12967-016-0786-z.

95. Sun M, Kraus WL. From discovery to function: the expanding roles of long NonCoding RNAs in physiology and disease. Endocr Rev. 2015;36(1):25-64 https://doi.org/10.1210/er.2014-1034.

96. Sun $\mathrm{M}$, Liu XH, Wang KM, et al. Down-regulation of BRAF activated noncoding RNA is associated with poor prognosis for non-small cell lung cancer and promotes metastasis by affecting epithelial-mesenchymal transition. Mol Cancer. 2014;13:68

97. Sun Y, Zou X, He J, Mao Y. Identification of long noncoding RNAs biomarkers associated with progression of endometrial carcinoma and patient outcomes. Oncotarget. 2017:8(32):52604-13.
98. Tano K, Mizuno R, Okada T, Rakwal R, Shibato J, et al. MALAT-1 enhances cell motility of lung adenocarcinoma cells by influencing the expression of motility-related genes. FEBS Lett. 2010;584:4575-80.

99. Tsai MC, Manor O, Wan Y, Mosammaparast N, Wang JK, Lan F, Shi Y, Segal E, Chang HY. Long noncoding RNA as modular scaffold of histone modification complexes. Science. 2010;329:689-93.

100. Wan LB, Bartolomei MS. Regulation of imprinting in clusters: noncoding RNAs vs insulators. Adv Genet. 2008;61:207-23.

101. Wang J, Du S, Wang J, Fan W, Wang P, Zhang Z, Xu P, Tang S, Deng Q, Yang W, Yu M. The prognostic value of abnormally expressed IncRNAs in colorectal cancer: a meta-analysis. PLoSOne. 2017a;12(6):e0179670. https:// doi.org/10.1371/journal.pone.0179670.

102. Wang J, Ye C, Xiong H, Shen Y, Lu Y, Zhou J, Wang L. Dysregulation of long noncoding RNA in breast cancer: an overview of mechanism and clinical implication. Oncotarget. 2017b;8(3):5508-22.

103. Wang KC, Chang HY. Molecular mechanisms of long noncoding RNAs. MolCell. 2011;43(6):904-14. https://doi.org/10.1016/j.molcel.2011.08.018.

104. Wang P, Ren Z, Sun P. Overexpression of the long noncoding RNA MEG3 impairs in vitro glioma cell proliferation. J Cell Biochem. 2012;113(6):1868-74.

105. Wang W, Zhuang Q, Ji K, Wen B, Lin P, Zhao Y, Li L, Yan C. Identification of miRNA, IncRNA and mRNA-associated ceRNA networks and a potential biomarker for MELAS with mitochondrial DNA A3243G mutation. Sci Rep. 2017c;7:41639. https://doi.org/10.1038/srep41639.

106. Wang X, Arai S, Song X, Reichart D, Du K, Pascual G, Tempst P, Rosenfeld MG, Glass CK, Kurokawa R. Induced ncRNAsallosterically modify RNA-binding proteins in cis to inhibit transcription. Nature. 2008:454:126-30.

107. White NM, Cabanski CR, Silva-Fisher JM, Dang HX, Govindan R, Maher CA. Transcriptome sequencing reveals altered long intergenic noncoding RNAs in lung cancer. Genome Biol. 2014;15:429.

108. Wight M, Werner A. The functions of natural antisense transcripts. Essays Biochem. 2015;54:91-101.

109. Wilusz JE, Sunwoo H, Spector DL. Long noncoding RNAs: functional surprises from the RNA world. Genes Dev. 2009:23:1494-504.

110. Wucherpfennig KW, Strominger JL. Molecular mimicry in T cell-mediated autoimmunity: viral peptides activate human $T$ cell clones specific for myelin basic protein. Cell. 1995;80(5):695-705.

111. Yang C, Chapman AG, Kelsey AD, Minks J, Cotton AM, Brown CJ. Xchromosome inactivation: molecular mechanisms from the human perspective. Hum Genet. 2011;130:175-85.

112. Yang JH, Li JH, Jiang S, Zhou H, Qu LH. ChIPBase: a database for decoding the transcriptional regulation of long noncoding RNA and microRNA genes from ChIP-Seq data. Nucleic Acids Res. 2013;41:D177-87.

113. Yap KL, Li S, Munoz-Cabello AM, Raguz S, Zeng L, Mujtaba S, Gil J, Walsh MJ, Zhou MM. Molecular interplay of the noncoding RNA ANRIL and methylated histone $\mathrm{H} 3$ lysine 27 by polycomb CBX7 in transcriptional silencing of INK4a. Mol Cell. 2010;38(5):662-74.

114. Zhang C, Gao L, Xu EYT. IncRNA, a new component of expanding RNAprotein regulatory network important for animal sperm development. Semin Cell Dev Biol. 2016;59:110-7.

115. Zhang $Q$, Geng $P L$, Yin $P$, Wang $X L$, Jia JP, Yao J. Down-regulation of long noncoding RNA TUG1 inhibits osteosarcoma cell proliferation and promotes apoptosis. Asian Pac J Cancer Prev. 2013;1:2311-5.

Ready to submit your research? Choose BMC and benefit from:

- fast, convenient online submission

- thorough peer review by experienced researchers in your field

- rapid publication on acceptance

- support for research data, including large and complex data types

- gold Open Access which fosters wider collaboration and increased citations

- maximum visibility for your research: over $100 \mathrm{M}$ website views per year

At $\mathrm{BMC}$, research is always in progress.

Learn more biomedcentral.com/submissions 